\title{
Development of an Analytical Method for the Rapid Quantitation of Peptides Used in Microbicide Formulations
}

\author{
Yufei Chen $\cdot$ Sidi Yang $\cdot$ Emmanuel A. Ho
}

Received: 21 July 2014 / Accepted: 25 September 2014 / Published online: 17 October 2014

(C) The Author(s) 2014. This article is published with open access at Springerlink.com

\begin{abstract}
Recently, a growing number of macromolecules such as peptides and proteins have been formulated into various microbicide formulations for the prevention of sexually transmitted infections. However, a fast and reliable high-throughput method for quantitating peptide/protein in polymer-based microbicide formulations is still lacking. As a result, we developed and validated a reversed-phase highperformance liquid chromatography method for the quantitation of gp120 fragment and LL-37 simultaneously in various microbicide gel formulations. This method was capable of detecting a limit of linearity (regression coefficient of 0.999) for gp120 fragment and LL-37 within a range of 0.625-80 and $1.25-80 \mu \mathrm{g} \mathrm{mL} \mathrm{m}^{-1}$, respectively. The lower limit of quantification for gp120 fragment and LL-37 was 1.14 and $0.31 \mu \mathrm{g} \mathrm{mL}^{-1}$, respectively. Method validation demonstrated acceptable intra- and inter-day RSD \% $(<5 \%)$ and accuracy (95.67-100.5\%). Formulating both peptides into polymeric pharmaceutical gel formulations showed high extraction efficiency (in the range of $95.90 \pm 3.03$ to $111.45 \pm 2.51 \%$ ). Using this method, we were able to separate and identify the forced degraded products from both peptides simultaneously without affecting the quantitation of both peptides in the polymeric dosage forms. Furthermore, this method was able to detect and separate degradants that were unable to be revealed using gel eletrophoresis.
\end{abstract}

Keywords Intravaginal gel Protein degradant . Reversed-phase HPLC · Tris-tricine SDS-PAGE . Separation

Y. Chen $\cdot$ S. Yang $\cdot$ E. A. Ho $(\bowtie)$

Laboratory for Drug Delivery and Biomaterials,

Faculty of Pharmacy, University of Manitoba, Apotex Centre, 750 McDermot Ave, Room 329, Winnipeg, MB R3E 0T5, Canada e-mail: emmanuel_ho@umanitoba.ca

\section{Introduction}

Sexually transmitted diseases (STDs) including human immunodeficiency virus (HIV)/acquired immunodeficiency syndrome (AIDS) present a huge threat globally, especially to women [1]. Women are biologically two times more likely than men to be infected by HIV via heterosexual intercourse. For example, after sexual intercourse, semen remains within the female genital tract for prolonged periods of time, increasing exposure to HIV. In the absence of an effective vaccine, microbicides are being developed for vaginal and rectal application as a strategy to prevent and/or reduce sexual transmission of HIV. The emergence of microbicides has greatly improved the feasibility for women to protect themselves because the use of microbicides is discreet without requiring co-operation or consent by their sexual partners [2,3]. Microbicides have been formulated into various dosage forms including gels, films, tablets, and vaginal rings [4-6]. The active microbicidal agent can vary from small molecule drugs [7] to large biomacromolecules such as peptides and proteins [8]. Peptides, as a class of anti-microbicidal agents, have gained extensive attention recently due to their highlighted properties such as their broad anti-microbial and immunomodulatory effects in comparison to chemical agents $[9,10]$.

However, the lack of reliable and rapid quantification methods for this class of microbicides presents as a great inconvenience to their researchers, especially analysts. Although there are several existing methods for protein/ peptide quantification such as spectrophotometry, western blot, and enzyme-linked immunosorbent assay (ELISA), their individual limitations hinder them from satisfying the needs of practical applications. For example, the commercially available BCA/Bradford assay based on spectrophotometry lacks specificity and sensitivity. These assays 
cannot distinguish between different proteins/peptides, and the lower limit of quantification (LLOQ) for the BCA assay that can be achieved without interference is approximately $1.23 \mu \mathrm{g} \mathrm{mL}{ }^{-1}$ [11]. Furthermore, the accuracy of these assays are significantly reduced when approaching the LLOQ and the results can be inconsistent due to interference by impurities or the presence of other substances, e.g., excess salts, surfactants, polymers, etc. [11].Western blot has good specificity in identifying the target protein/ peptide. It is a semi-quantitative method and is time-consuming, especially for the detection of small peptides due to the much higher degree of cross-linked gel matrix required, thus resulting in significantly longer electrophoresis runtime. ELISA is a reliable method with both specificity and accuracy, but the sample analysis is generally time-consuming requiring optimization of appropriate antibody/antigen incubation and can be expensive due to the need of antibodies with high specificity, thereby affecting its efficiency for analyzing large quantities of pharmaceutical samples. In contrast, reversed-phase high-performance liquid chromatography (RP-HPLC) has good precision $(<2 \%)$, acceptable selectivity and sensitivity (as low as $0.33 \mu \mathrm{g} \mathrm{mL}^{-1}$ ), relatively inexpensive (e.g., does not require the use of antibodies) and is less time-consuming than traditional protein analysis methods (e.g., gel electrophoresis) [11, 12].

In the current study, our group has developed a rapid and sensitive RP-HPLC quantification method for two peptides, gp120 fragment (encompassing the CD4 binding site) and LL-37, with potential applications in microbicide development. To the best of our knowledge, this is the first paper focusing on developing an accurate, rapid, robust and convenient analysis method that can be used to analyze these microbicidal peptides in polymeric gel formulations. LL-37 is the only cathelicidin host defense peptide found in humans $[13,14]$. LL-37 has been shown to exhibit antibacterial [15], anti-fungal [16], anti-viral [17, 18], wound healing [19, 20], anticancer [21, 22], and immunomodulatory activity [23]. Glycoprotein 120 (gp120) is part of the HIV envelope protein and its fragment (target analyte in current study) has been used for the induction of anti-HIV neutralization antibodies [24, 25]. Although there are published literatures reporting the use of RP-HPLC for the purification of LL-37 [26, 27], to the best of our knowledge, there is no validated RP-HPLC method for determining the concentration of LL-37 or gp120 fragment alone or simultaneously. The current study is the first to apply a validated RPHPLC method for the simultaneous quantification of LL-37 and gp120 fragment in polymeric gel dosage forms. Since peptides are generally unstable under certain environmental conditions resulting in degradation and/or aggregation, we further evaluated the application of the current RPHPLC method for identifying the degradation or aggregation products of both peptides. This method is rapid, robust and convenient when developing novel microbicide gel formulations.

\section{Materials and Methods}

\section{Materials}

Water and acetonitrile (HPLC grade) were purchased from EMD (Mississauga, ON, Canada). LL-37 (4,493.33 Da, LLGDFFRKSKEKIGKEFKRIVQRIKDFLRNLVPRTES) and gp120 fragment $(2,138.56 \mathrm{Da}$, KQFINMWQEVGKAMYAPP) were custom synthesized by CPC Scientific Inc. (Sunnyvale, CA, USA) and Biomatik Corp. (Cambridge, ON, Canada), respectively. Hydroxyethylcellulose (HEC) (Natrosol ${ }^{\mathrm{TM}}$, 250 HX PHARM) was a kind gift from Ashland Inc. (Covington, KY, USA). Hydroxypropyl methylcellulose (HPMC, Methocel E4 M Premium) was kindly supplied by The Dow Chemical Company (Calgary, Alberta, Canada) and hydroxypropyl cellulose (HPC) (4,000-6,500 cps) was purchased from Spectrum Chemical Manufacturing Corp. (New Brunswick, NJ, USA). Glycerol, trifluoroacetic acid (TFA), acetic acid and dipotassium phosphate were purchased from Fisher Scientific (Ottawa, ON, Canada).

\section{RP-HPLC Method}

Stock solutions of both peptides $\left(1 \mathrm{mg} \mathrm{mL}{ }^{-1}\right)$ were prepared in water. Working standard solutions were prepared from the stock solutions covering the range of 0.625 $80 \mu \mathrm{gL}^{-1}(n=6)$. Quantification of gp120 fragment and LL-37 was performed using a gradient RP-HPLC method. Analysis was performed using a XBridge ${ }^{\mathrm{TM}} \mathrm{BEH} 300 \mathrm{C} 18$ column (300 ̊, $5 \mu \mathrm{m} 4.6 \times 150 \mathrm{~mm}$; Waters) with a Symmetry C18 guard column $(300 \AA, 5 \mu \mathrm{m}, 3.9 \times 20 \mathrm{~mm}$; Waters), fitted to a Waters ${ }^{\circledR}$ Alliance ${ }^{\circledR}$ HPLC system equipped with Waters ${ }^{\circledR} 2690$ Separations module and Waters ${ }^{\circledR} 996$ Photodiode Array detector. Mobile phase A consisted of $0.1 \%$ TFA in $10 \%$ acetonitrile in HPLC grade water. Mobile phase B consisted of $0.85 \%$ TFA in $90 \%$ acetonitrile in water. A gradient $\mathrm{A} / \mathrm{B}$ was applied to elute and analyze the peptides: A/B from $85: 15$ to $20: 80$ in $6 \mathrm{~min}$, followed by maintaining at $20: 80$ for $2 \mathrm{~min}$ and reequilibration of the column at 85:15. Total run was $10 \mathrm{~min}$ for each $200 \mu \mathrm{L}$ injection. Flow rate was $2.0 \mathrm{~mL} \mathrm{~min}{ }^{-1}$, UV detection was set at $210 \mathrm{~nm}$, and column temperature was maintained at $60{ }^{\circ} \mathrm{C}$. The retention time for gp120 and LL-37 were approximately $2.7 \mathrm{~min}$ and $4.1 \mathrm{~min}$, respectively. The linear calibration curves for gp120 and LL-37 were obtained in the range of $0.625-80 \mu \mathrm{g} \mathrm{mL}$ $\left(R^{2}>0.999\right)$ and $1.25-80 \mu \mathrm{g} \mathrm{mL}^{-1}\left(R^{2}>0.999\right)$, respectively $(n=6)$. 
Preparation and Extraction of LL-37/gp120

from Polymeric Microbicide Gels

Approximately $1 \mathrm{~g}$ of HEC, HPMC, or HPC ( $2 \%$ ) was added to $40 \mathrm{~mL}$ of $\mathrm{KH}_{2} \mathrm{PO}_{4}(\mathrm{pH} 7.4)$ and stirred at $4{ }^{\circ} \mathrm{C}$ for $2 \mathrm{~h}$ until dissolved. To adjust the viscosity of the gel to be similar to gels used for microbicide evaluation (e.g., $\sim 2,736 \mathrm{cP})$ [28], $5 \mathrm{~g}$ of glycerol $(10 \%)$ was added and stirred until it was uniformly dispersed. Water was used to dissolve gp120 and $20 \%$ acetic acid was used to dissolve LL-37 to make a concentration of $1 \mathrm{mg} \mathrm{mL}{ }^{-1}$. Each peptide was mixed with the gels at a weight ratio of 1:1:4,000 (gp120:LL-37:gel) and stirred at $4{ }^{\circ} \mathrm{C}$ for $2 \mathrm{~h}$ resulting in a preparation containing $1 \%$ HEC, HPMC, or HPC gel loaded with gp120 $(0.025 \%$, w/w $)$ and LL-37 $(0.025 \%$, $\mathrm{w} / \mathrm{w})$.

For the extraction of peptides from polymeric gels, approximately $200 \mathrm{mg}$ of the gel was weighed into a 5 -mL volumetric flask and filled to volume with HPLC grade water. The sample was vortexed at room temperature for $30 \mathrm{~s}$ (three runs of $10 \mathrm{~s}$ each) and sonicated on ice for another $20 \mathrm{~s}$ (two runs of $10 \mathrm{~s}$ each). The extraction samples were then analyzed on RP-HPLC. To determine the extraction efficiency (assayed peptide concentration in the gel divided by the theoretical concentration in the gel), blank gels were spiked with known amounts of gp120 and LL-37 followed by the extraction procedure as described above.

\section{Forced Heat-Stress Studies}

Both gp120 and LL-37 were exposed to various environmental conditions to force degrade the peptides. Since these peptides may be used for microbicide development, vaginal fluid simulant (VFS; $60 \mathrm{mM} \mathrm{NaCl}, 25 \mathrm{mM} \mathrm{KOH}$, $3 \mathrm{mM} \mathrm{Ca}(\mathrm{OH})_{2}, 6.6 \mathrm{mM}$ urea, $28 \mathrm{mM}$ glucose, $22 \mathrm{mM}$ lactic acid, $16.7 \mathrm{mM}$ acetic acid, $1.7 \mathrm{mM}$ glycerol, $\mathrm{pH}$ 4.2) [29] was used for the stability studies. Both peptides were freshly dissolved in VFS separately to yield a $1 \mathrm{mg}$ $\mathrm{mL}^{-1}$ solution. Aliquots of both peptides $(200 \mu \mathrm{L})$ were then heat-stressed using a heating block at $95{ }^{\circ} \mathrm{C}$ for up to $8 \mathrm{~h}$. The samples were then allowed to cool down to room temperature and stored at $-20{ }^{\circ} \mathrm{C}$ prior to analysis. Nonheat-stressed samples were immediately stored at $-20{ }^{\circ} \mathrm{C}$ after dissolving the peptides. The collected samples were analyzed either using the same RP-HPLC method described above or using tris-tricine SDS-PAGE [30]. For tris-tricine SDS-PAGE, stressed and non-stressed peptides $(10 \mu \mathrm{g})$ were mixed with $5 \mu \mathrm{L}$ of $3 \times$ sample loading buffer without 2-mercaptoethanol and loaded on to a tris-tricine gel, containing a stacking gel $(4 \% T, 3 \% \mathrm{C}$, which $T$ is for total acrylamide concentration and $C$ is for crosslinker concentration), spacer gel $(10 \% T, 6 \% C)$, and a separating gel $(16 \% T, 6 \% C)$. Electrophoresis was performed at room temperature with an initial voltage of $30 \mathrm{~V}$ until the samples completely migrated into the spacer gel, followed by four incremental increases in voltage (15 V per increment) to a final voltage of $90 \mathrm{~V}$ until the tracking dye reached the bottom of the gel. After $5 \mathrm{~h}$ of electrophoresis, resolved peptides and their degradation/aggregation products were visualized using a rapid Coomassie Blue R-250 staining method [31]. Target degradation/aggregation peptide bands were then carefully cut from the gels and recovered by electro-elution. Briefly, gel slices containing the aggregation bands of interest (combined from 6 to 8 gels to increase recovery) were encased in a Spectra/Por ${ }^{\circledR}$ Micro Float-A-Lyzer dialysis device (0.5-1 kDa MWCO Spectrum Laboratories, Inc., Compton, CA, USA) and immersed in transfer buffer (25 mM tris, $192 \mathrm{mM}$ glycine, $20 \%$ methanol v/v, $\mathrm{pH}$ 8.3). Electro-elution was conducted at $100 \mathrm{~V}$ for $1.5 \mathrm{~h}$ to ensure complete migration of peptide samples out of the gel matrix. After overnight dialysis against PBS ( $\mathrm{pH}$ 7.4) at $4{ }^{\circ} \mathrm{C}$ to remove residual SDS, samples were freezedried using a benchtop freeze dry system (Labconco ${ }^{\circledR}$ FreeZone 2.5 Liter). Lyophilized peptides and their aggregation products were re-solubilized in $250 \mu \mathrm{L}$ double distilled water and immediately subjected to RP-HPLC analysis. Heat-stressed peptides were then used to spike HPC, HPMC, and HEC gels, and peptide extraction/RP-HPLC analysis was performed as described earlier.

Statistical Analysis

Data are expressed as the mean \pm standard deviation (SD) from the obtained results. Student's $t$ test was performed using GraphPad Prism version 6.0c (GraphPad Software, La Jolla California USA). $P<0.05$ was considered as statistically significant.

\section{Results}

\section{Method Validation}

Linearity was determined from a calibration curve using standards of gp120 and LL-37 solutions in the range of $0.625-80 \mu \mathrm{g} \mathrm{mL}^{-1}$ in water and with six replicates. Linear relationship was observed between the peak area and the concentrations of peptides in water as reported in Table 1 with a regression coefficient of 0.999 . The lower limit of detection (LLOD) and LLOQ were obtained as defined by the International Conference on Harmonisation (ICH) Topic Q2B [32] using the slope (b) of the calibration curve 
Table 1 Method validation of RP-HPLC for gp120 fragment and LL-37

\begin{tabular}{|c|c|c|c|c|c|c|c|c|c|c|}
\hline \multirow{2}{*}{$\begin{array}{l}\text { Conc. } \\
\left(\mu \mathrm{g} \mathrm{mL}^{-1}\right)\end{array}$} & \multirow[t]{2}{*}{$R$} & \multirow[t]{2}{*}{ Equation } & \multicolumn{2}{|l|}{ Mean \pm SD } & \multicolumn{2}{|l|}{$\%$ RSD } & \multicolumn{2}{|c|}{ Accuracy (\%) } & \multirow{2}{*}{$\begin{array}{l}\operatorname{LLOD}(\mu \mathrm{g} \\
\left.\mathrm{mL}^{-1}\right)\end{array}$} & \multirow{2}{*}{$\begin{array}{l}\text { LLOQ }(\mu \mathrm{g} \\
\left.\mathrm{mL}^{-1}\right)\end{array}$} \\
\hline & & & Intra-day & Inter-day & Intra-day & Inter-day & Intra-day & Inter-day & & \\
\hline \multicolumn{11}{|l|}{ gp120 } \\
\hline 5 & \multirow[t]{3}{*}{0.999} & \multirow{3}{*}{$\begin{array}{c}Y=97,794.50 \\
( \pm 1,128.59) \times \\
X+8,627.98 \\
( \pm 3,050.39)\end{array}$} & $4.84 \pm 0.12$ & $5.02 \pm 0.10$ & 1.27 & 0.47 & 96.38 & 100.4 & 0.10 & 0.31 \\
\hline 15 & & & $14.97 \pm 0.32$ & $15.04 \pm 0.33$ & 0.28 & 0.23 & 100.36 & 100.5 & & \\
\hline 40 & & & $40.02 \pm 0.17$ & $39.93 \pm 0.47$ & 0.37 & 0.43 & 99.87 & 99.87 & & \\
\hline \multicolumn{11}{|l|}{ LL-37 } \\
\hline 5 & \multirow[t]{3}{*}{0.999} & \multirow{3}{*}{$\begin{array}{c}Y=64,831.25 \\
( \pm 682.50) \times \\
X+14,115.90 \\
( \pm 7,384.79)\end{array}$} & $4.91 \pm 0.42$ & $5.02 \pm 0.31$ & 1.45 & 0.87 & 95.67 & 98.97 & 0.38 & 1.14 \\
\hline 10 & & & $15.05 \pm 0.37$ & $15.01 \pm 0.28$ & 0.93 & 0.88 & 97.45 & 98.45 & & \\
\hline 40 & & & $39.93 \pm 0.26$ & $40.04 \pm 0.32$ & 0.82 & 0.21 & 97.23 & 100.23 & & \\
\hline
\end{tabular}

$R$ regression coefficient, $L L O D$ lower limit of detection, $L L O Q$ lower limit of quantification

Table 2 Extraction of gp120 fragment and LL-37 from different polymeric gels

\begin{tabular}{lclrl}
\hline Type of gels & EE of gp120 $(\%)$ & Concentration of gp120 (w/w, \%) & EE of LL-37 (\%) & Concentration of LL-37 (w/w, \%) \\
\hline $1 \%$ HEC gel & $95.90 \pm 3.03$ & $0.0241 \pm 0.0008$ & $98.27 \pm 2.51$ & $0.0240 \pm 0.0008$ \\
$1 \%$ HPMC gel & $106.33 \pm 2.46$ & $0.0236 \pm 0.0006$ & $105.66 \pm 3.16$ & $0.0238 \pm 0.0004$ \\
$1 \%$ HPC gel & $101.07 \pm 4.02$ & $0.0241 \pm 0.0001$ & $111.45 \pm 2.51$ & $0.0248 \pm 0.0005$ \\
\hline
\end{tabular}

Data represent mean $\pm \mathrm{SD}, n=6$

$E E$ extraction efficiency (\%)

and the standard deviation, $S a$, of the intercept (a) using the equations below:

LLOD $=3.3 \times \frac{S a}{b}$

$\mathrm{LLOQ}=10 \times \frac{S a}{b}$

Accuracy values were determined via the following equation and were always within the acceptable limits $( \pm 5 \%)$ at all validation concentrations (Table 1$)$.

Accuracy $(\%)=\frac{(\text { True value }- \text { Measured value })}{\text { True value }} \times 100$

Precision was determined from three standard calibration curves. Two were from the same day for intra-day precision and the third one was from a different day for inter-day precision. Intra- and inter-day precision was evaluated by analyzing both peptides at low $\left(5 \mu \mathrm{L} \mathrm{mL}^{-1}\right)$, medium $\left(15 \mu \mathrm{L} \mathrm{mL}{ }^{-1}\right)$, and high $\left(40 \mu \mathrm{L} \mathrm{mL}^{-1}\right)$ concentrations $(n=6$, Table 1$)$. The relative standard deviation (\%RSD) values were calculated for each concentration. The precision was found to be acceptable $(<5 \%)$, with the $\%$ RSD values of intra-day precision ranging $0.28-1.27 \%$ for gp120 and $0.85-1.45 \%$ for LL-37 as well as the $\%$ RSD values of inter-day precision ranging $0.23-$ $0.47 \%$ for gp 120 and $0.21-0.87 \%$ for LL-37. The determined LLOD and LLOQ for gp120 were 0.10 and $0.31 \mu \mathrm{L} \mathrm{mL}^{-1}$, while for LL-37 the values were 0.38 and $1.14 \mu \mathrm{L} \mathrm{mL}^{-1}$, respectively. The assayed accuracy for the lower concentrations approaching the LLOQ of gp120 fragment (at $0.625 \mu \mathrm{g}$ $\mathrm{mL}^{-1}$ ) and LL-37 (at $1.25 \mu \mathrm{g} \mathrm{mL}^{-1}$ ) were $114.5 \pm 7.5 \%$ and $115.5 \pm 0.09 \%$, respectively $(n=3)$.

Peptide Extraction from Gels and Peptide Separation by RP-HPLC Method

To evaluate whether current RP-HPLC method was suitable for the quantification of both peptides within polymeric matrices, this method was applied towards the extraction of both gp120 fragment and LL-37 simultaneously from HEC, HPMC, and HPC gels. Results showed that both peptides were successfully extracted from all polymeric gels with high extraction efficiency ranging from $95.90 \pm 3.03$ to $106.33 \pm 2.46 \%$ for gp120 fragment and from $98.27 \pm 2.51$ to $111.45 \pm 2.51 \%$ for LL-37, respectively (Table 2). The loadings of both peptides in the polymeric gel formulations were found in the range 0.0236-0.0241\% for gp120 fragment and 0.0238-0.0248\% for LL-37 using the current extraction procedure (Table 2).

Identification of gp120 Fragment and LL-37 Degradation/ Aggregation Products

Using the current validated method that was developed for quantitating gp120 fragment and LL-37, separation of heat-stressed peptides under acidic exposure was achieved (Fig. 2a, b). There were two distinct gp120 fragment 

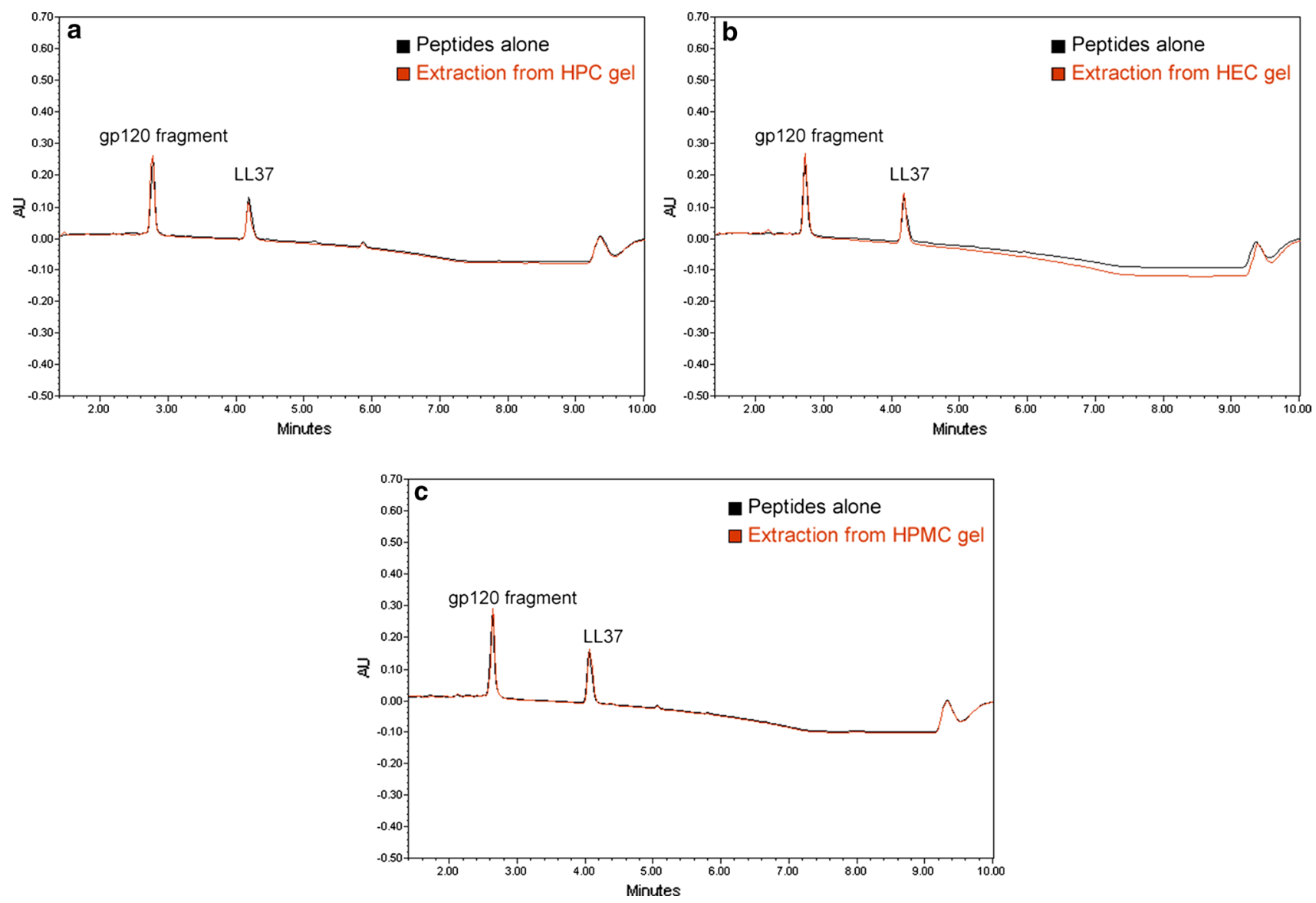

Fig. 1 Extraction of gp120 fragment and LL-37 from polymeric gels. Chromatograms of gp120 fragment and LL-37 before and after extraction from a HPC, b HEC and $\mathbf{c}$ HPMC gels via the current RP-
HPLC method. Each representative chromatogram was obtained from repetitive RP-HPLC analysis $(n=6)$
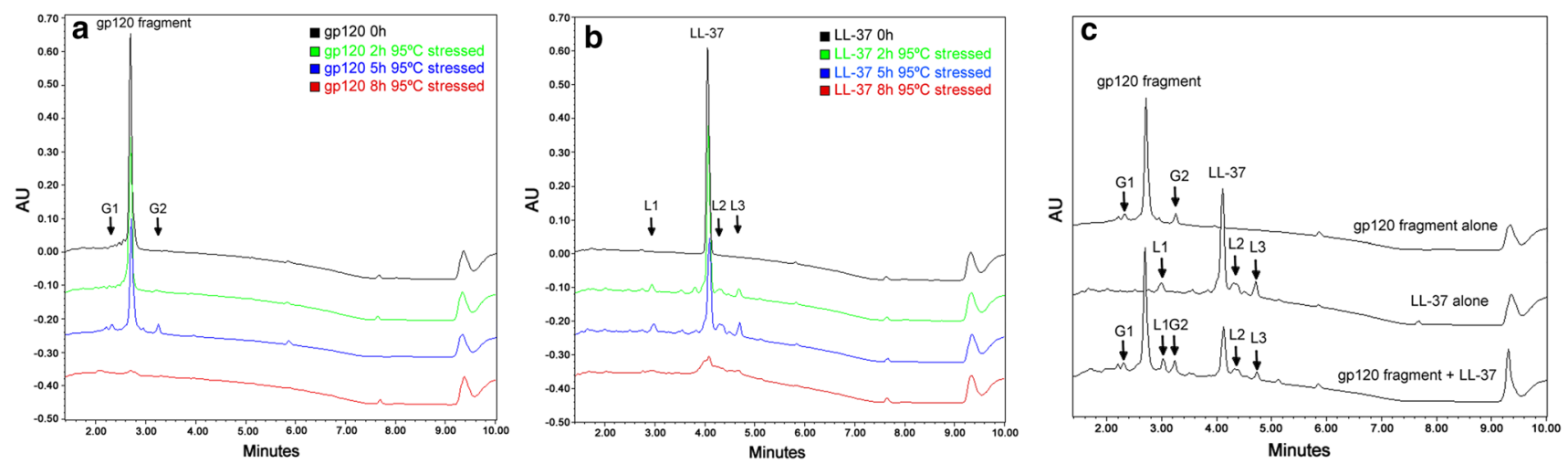

Fig. 2 Overlay chromatograms of forced degraded peptides. RPHPLC overlay chromatograms showing the detection and separation of heat-stressed gp120 fragment alone (a heat-stressed up to 8 h), LL-37 alone (b heat-stressed up to 8 h), both gp120 fragment and LL-37 analyzed simultaneously comparing to individual peptide chromatograms (c heat-stressed for $5 \mathrm{~h}$, spiked into HEC gel) using
RP-HPLC. Peaks G1 and G2 represent the force-degraded peaks of gp120 fragment while peaks L1-3 represent LL-37 forced degraded product peaks. The representative chromatogram demonstrated was obtained from repetitive measurements with polymeric gels spiked with both peptides $(n=3)$ 
degradants and three LL-37 degradants identified using the current RP-HPLC method (Fig. 2a, b). The induced gp120 fragment degradants were found to have retention times of approximately $2.2 \mathrm{~min}(\mathrm{G} 1)$ and $3.2 \mathrm{~min}(\mathrm{G} 2)$ while LL-37 degradants with retention time of $2.9 \mathrm{~min}$ (L1), $4.4 \mathrm{~min}$ (L2), and $4.7 \mathrm{~min}$ (L3). It was also shown in Fig. 2c that the current method could successfully separate all identified forced degradants from gp120 fragment and LL-37 peaks in the presence of polymers. However, prolonged exposure to stressed conditions ( $>5 \mathrm{~h}$ ) resulted in a decrease and/ or absence of peaks for gp120 fragment, LL-37, and their forced degraded products (Figs. 2a, c, 3). Further identification of LL-37 forced degraded products revealed that L2 and L3 were approximately 12 and $16 \mathrm{kDa}$, respectively (Fig. 3a, b).

\section{Discussion}

In the current study, we have developed an accurate and precise RP-HPLC method with validation for quantitating two peptides simultaneously, gp120 fragment and LL-37, formulated in three polymeric hydrophilic gel formulations with acceptable reproducibility. According to the chromatograms, there was little to no interference caused by the polymeric gels using the current RP-HPLC method with respect to peak shape and peak area (Fig. 1). This could be attributed to the hydrophilic property of the polymers tested in the current study resulting in negligible interactions with the analytical column [11]. In RP-HPLC, hydrophobic molecules (in current study, the two peptides) are first adsorbed onto the hydrophobic stationary phase (e.g., C18 column) in a polar mobile phase and can be later eluted by decreasing the polarity of the mobile phase through the
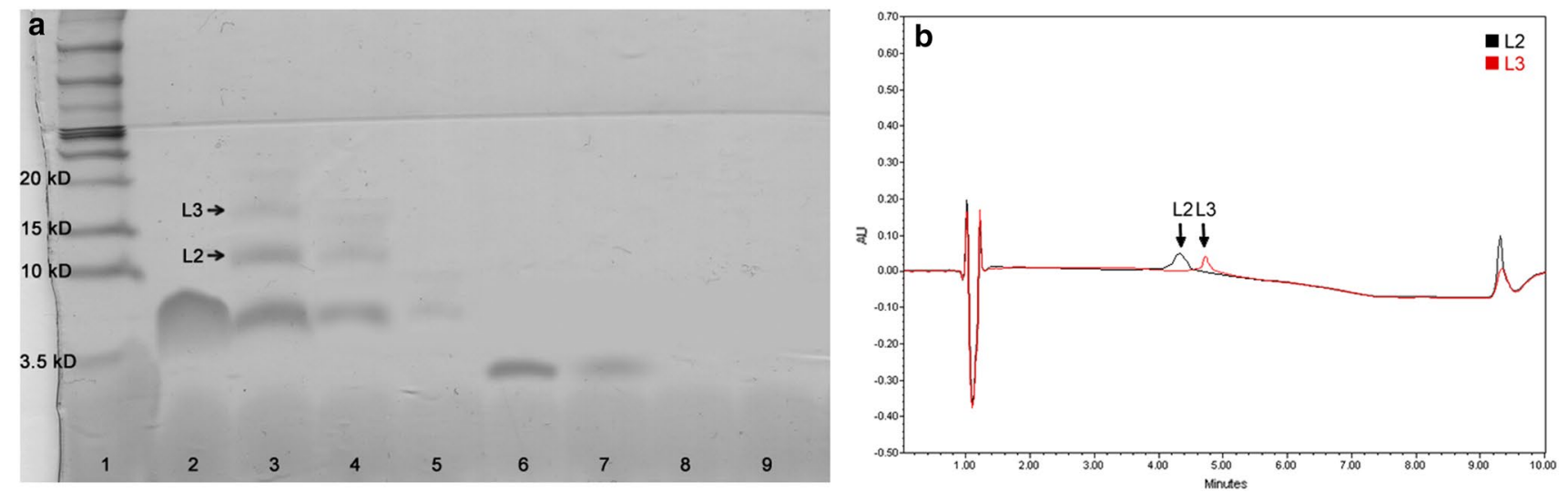

Fig. 3 Gel electrophoresis and RP-HPLC detection of forced degraded products. Tris-tricine SDS-PAGE of heat-stressed gp120 fragment and LL-37 samples (a) and the overlay chromatogram of LL-37 forced degraded products (b). Lane $1 \mathrm{MW}$ markers; lane 2 LL-37 non-stressed; lanes 3-5 LL-37 heat-stressed for 2, 5, $8 \mathrm{~h}$; introduction of acetonitrile [11]. Furthermore, our gradient method was capable of simultaneously separating both peptides without any overlap in peaks (Fig. 1). LL-37 and gp120 fragment exhibit different hydrophobicities with an estimated relative hydrophobicity value of 52.62 and 42.16 , respectively, as predicated by the current algorithm SSRCalc prediction model (http://hs2.proteome.ca/SSRCalc/ SSRCalcX.html, using a $300 \AA$ C18 column in $0.1 \%$ TFA) [33]. This prediction model takes into consideration various parameters which may influence peptide behavior such as amino acid composition, the nature of $\mathrm{N}$ - and $\mathrm{C}$-terminal residues, peptide length, and $\mathrm{p} I$, etc. [34].Thus, the slightly higher relative hydrophobicity of LL-37 may explain the later elution of this peptide compared to gp120 fragment (Fig. 1).

Since microbicides are usually applied topically to the vagina, peptides formulated in a polymeric pharmaceutical dosage needs to be stable within their surrounding environment, e.g., the physiological temperature of the female genital tract is $37{ }^{\circ} \mathrm{C}$ and vaginal fluid is acidic ( $\mathrm{pH} \mathrm{3.5-4.9)}$ [29]. These conditions may potentially increase the degradation rate of proteins and peptides [29]. Thus, we further evaluated the utility of the current RP-HPLC method to: (1) distinguish forced degradation products of both peptides and (2) quantitate the residual peptides within the polymeric gels without any interference. Under forced degradative conditions for up to $8 \mathrm{~h}\left(95^{\circ} \mathrm{C}\right.$ in $\mathrm{pH} 4.2$ buffer), the current method was able to differentiate between the degraded products for gp120 (G1-2) and LL-37 (L1-3) (Fig. 2), and was successful in separating the peptide peaks while in the presence of all three polymers (Fig. 2c, a representative spiked HEC gel analysis was presented and similar chromatograms were observed using HPC and HPMC gels). These observations were supported by the lane 6 gp120 fragment non-stressed; lanes 7-9 gp120 fragment heatstressed for 2, 5, $8 \mathrm{~h}$. Force-degraded bands ( $L 2$ and $L 3)$ of LL-37 were extracted from the gel and analyzed using RP-HPLC. Each representative chromatogram was obtained from repeated gel electrophoresis $(n=3)$ and RP-HPLC analysis $(n=3)$ 
tris-tricine SDS-PAGE results (Fig. 3a). Moreover, the current RP-HPLC method was able to identify and differentiate the forced degraded products, which cannot be detected by tris-tricine SDS-PAGE, e.g., products $\mathrm{G} 1, \mathrm{G} 2$, and L1 (Fig. 2). The absent peaks of gp120 fragment, LL-37, and their degradation products after prolonged $(>5 \mathrm{~h})$ heat/ acid exposure (Fig. 2a, b) could be attributed to the severe degree of hydrolytic cleavage (breaking down into amino acids) of both peptides and the degradants $[35,36]$.

\section{Conclusions}

In the current study, we developed a fast, accurate, and reliable RP-HPLC method for the quantitation of two candidate microbicide peptides, LL-37 and gp120 fragment simultaneously in polymeric gel formulations. This method was able to detect and separate the forced degraded products of both peptides simultaneously in the presence of polymers without any interference or affecting the determination of peptide concentration, providing a quick and precise alternative to LC-MS techniques.

Acknowledgments This work was supported in part by a Canadian Institutes of Health Research Operating Grant (MOP110981) and a Manitoba Health Research Council Establishment Grant awarded to Dr. Emmanuel A. Ho. Yufei Chen and Sidi Yang are both grateful for the financial support received from the Manitoba Health Research Council Graduate Studentship.

Conflict of interest All the authors clarify that they have no conflicts of interest to declare.

Open Access This article is distributed under the terms of the Creative Commons Attribution License which permits any use, distribution, and reproduction in any medium, provided the original author(s) and the source are credited.

\section{References}

1. Da Ros CT, Schmitt Cda S (2008) Global epidemiology of sexually transmitted diseases. Asian J Androl 10(1):110-114. doi:10.1111/j.1745-7262.2008.00367.x

2. Lerner S (1994) Microbicides: a woman-controlled HIV prevention method in the making. SIECUS Rep 22(5):10-13

3. International Working Group on Vaginal Microbicides (1996) Recommendations for the development of vaginal microbicides. AIDS 10:1-6

4. Buckheit RW Jr, Watson KM, Morrow KM, Ham AS (2010) Development of topical microbicides to prevent the sexual transmission of HIV. Antiviral Res 85(1):142-158. doi:10.1016/j. antiviral.2009.10.013

5. Yang S, Chen Y, Ahmadie R, Ho EA (2013) Advancements in the field of intravaginal siRNA delivery. J Control Release 167(1):29-39. doi:10.1016/j.jconrel.2012.12.023

6. Yang S, Chen Y, Gu K, Dash A, Sayre CL, Davies NM, Ho EA (2013) Novel intravaginal nanomedicine for the targeted delivery of saquinavir to CD4+ immune cells. Int J Nanomed 8:28472858. doi:10.2147/IJN.S46958
7. Abdool Karim Q, Abdool Karim SS, Frohlich JA, Grobler AC, Baxter C, Mansoor LE, Kharsany AB, Sibeko S, Mlisana KP, Omar Z, Gengiah TN, Maarschalk S, Arulappan N, Mlotshwa M, Morris L, Taylor D, Group CT (2010) Effectiveness and safety of tenofovir gel, an antiretroviral microbicide, for the prevention of HIV infection in women. Science 329(5996):1168-1174. doi:10.1126/science. 1193748

8. Balzarini J, Schols D (2012) Combination of antiretroviral drugs as microbicides. Curr HIV Res 10(1):53-60

9. Steinberg DA, Hurst MA, Fujii CA, Kung AH, Ho JF, Cheng FC, Loury DJ, Fiddes JC (1997) Protegrin-1: a broad-spectrum, rapidly microbicidal peptide with in vivo activity. Antimicrob Agents Chemother 41(8):1738-1742

10. Bjorn C, Hakansson J, Myhrman E, Sjostrand V, Haug T, Lindgren K, Blencke HM, Stensvag K, Mahlapuu M (2012) Antiinfectious and anti-inflammatory effects of peptide fragments sequentially derived from the antimicrobial peptide centrocin 1 isolated from the green sea urchin Strongylocentrotus droebachiensis. AMB Express 2(1):67. doi:10.1186/2191-0855-2-67

11. Umrethia M, Kett VL, Andrews GP, Malcolm RK, Woolfson AD (2010) Selection of an analytical method for evaluating bovine serum albumin concentrations in pharmaceutical polymeric formulations. J Pharm Biomed Anal 51(5):1175-1179. doi:10.1016/j.jpba.2009.12.004

12. Grotefend S, Kaminski L, Wroblewitz S, Deeb SE, Kuhn N, Reichl S, Limberger M, Watt S, Watzig H (2012) Protein quantitation using various modes of high performance liquid chromatography. J Pharm Biomed Anal 71:127-138. doi:10.1016/j. jpba.2012.08.024

13. Cowland JB, Johnsen AH, Borregaard N (1995) hCAP18, a cathelin/pro-bactenecin-like protein of human neutrophil specific granules. FEBS Lett 368(1):173-176. doi:10.1016/0014-5793(95)00634-L

14. Wang G (2014) Human antimicrobial peptides and proteins. Pharmaceuticals (Basel) 7(5):545-594. doi:10.3390/ph7050545

15. Turner J, Cho Y, Dinh NN, Waring AJ, Lehrer RI (1998) Activities of LL-37, a cathelin-associated antimicrobial peptide of human neutrophils. Antimicrob Agents Chemother 42(9):2206-2214

16. Murakami M, Lopez-Garcia B, Braff M, Dorschner RA, Gallo RL (2004) Postsecretory processing generates multiple cathelicidins for enhanced topical antimicrobial defense. J Immunol 172(5):3070-3077

17. Gordon YJ, Huang LC, Romanowski EG, Yates KA, Proske RJ, McDermott AM (2005) Human cathelicidin (LL-37), a multifunctional peptide, is expressed by ocular surface epithelia and has potent antibacterial and antiviral activity. Curr Eye Res 30(5):385-394. doi:10.1080/02713680590934111

18. Wong JH, Legowska A, Rolka $\mathrm{K}, \mathrm{Ng} \mathrm{TB}$, Hui $\mathrm{M}$, Cho $\mathrm{CH}$, Lam WW, Au SW, Gu OW, Wan DC (2011) Effects of cathelicidin and its fragments on three key enzymes of HIV-1. Peptides 32(6):1117-1122. doi:10.1016/j.peptides.2011.04.0 17S0196-9781(11)00166-5

19. Ramos R, Silva JP, Rodrigues AC, Costa R, Guardao L, Schmitt F, Soares R, Vilanova M, Domingues L, Gama M (2011) Wound healing activity of the human antimicrobial peptide LL37. Peptides 32(7):1469-1476. doi:10.1016/j.peptides.2011.06.0 05S0196-9781(11)00229-4

20. Park HJ, Cho DH, Kim HJ, Lee JY, Cho BK, Bang SI, Song SY, Yamasaki K, Di Nardo A, Gallo RL (2009) Collagen synthesis is suppressed in dermal fibroblasts by the human antimicrobial peptide LL-37. J Investig Dermatol 129(4):843-850. doi:10.1038/ Jid.2008.320

21. Ren SX, Cheng AS, To KF, Tong JH, Li MS, Shen J, Wong CC, Zhang L, Chan RL, Wang XJ, Ng SS, Chiu LC, Marquez VE, Gallo RL, Chan FK, Yu J, Sung JJ, Wu WK, Cho CH (2012) Host immune defense peptide LL-37 activates caspase-independent 
apoptosis and suppresses colon cancer. Cancer Res 72(24):65126523. doi:10.1158/0008-5472.CAN-12-2359

22. Buchau AS, Morizane S, Trowbridge J, Schauber J, Kotol P, Bui JD, Gallo RL (2010) The host defense peptide cathelicidin is required for NK cell-mediated suppression of tumor growth. $\mathrm{J}$ Immunol 184(1):369-378. doi:10.4049/jimmunol.0902110

23. Nijnik A, Hancock RE (2009) The roles of cathelicidin LL-37 in immune defences and novel clinical applications. Curr Opin Hematol 16(1):41-47

24. Barnett SW, Rajasekar S, Legg H, Doe B, Fuller DH, Haynes JR, Walker CM, Steimer KS (1997) Vaccination with HIV 1 gp120 DNA induces immune responses that are boosted by a recombinant gp120 protein subunit. Vaccine 15(8):869-873. doi:10.1016/ S0264-410x(96)00264-2

25. Morrow WJ, Williams WM, Whalley AS, Ryskamp T, Newman R, Kang CY, Chamat S, Kohler H, Kieber-Emmons T (1992) Synthetic peptides from a conserved region of gp120 induce broadly reactive anti-HIV responses. Immunology 75(4):557-564

26. Krahulec J, Hyrsova M, Pepeliaev S, Jilkova J, Cerny Z, Machalkova J (2010) High level expression and purification of antimicrobial human cathelicidin LL-37 in Escherichia coli. Appl Microbiol Biotechnol 88(1):167-175. doi:10.1007/ s00253-010-2736-7

27. Li Y, Li X, Li H, Lockridge O, Wang G (2007) A novel method for purifying recombinant human host defense cathelicidin LL-37 by utilizing its inherent property of aggregation. Protein Expr Purif 54(1):157-165. doi:10.1016/j.pep.2007.02.003

28. Rohan LC, Moncla BJ, Kunjara Na Ayudhya RP, Cost M, Huang Y, Gai F, Billitto N, Lynam JD, Pryke K, Graebing P, Hopkins N, Rooney JF, Friend D, Dezzutti CS (2010) In vitro and ex vivo testing of tenofovir shows it is effective as an HIV-1 microbicide. PLoS One 5(2):e9310. doi:10.1371/journal.pone.0009310

29. Owen DH, Katz DF (1999) A vaginal fluid simulant. Contraception 59(2):91-95

30. Schagger H (2006) Tricine-SDS-PAGE. Nat Protoc 1(1):16-22. doi:10.1038/nprot.2006.4

31. Dong WH, Wang TY, Wang F, Zhang JH (2011) Simple, timesaving dye staining of proteins for sodium dodecyl sulfate-polyacrylamide gel electrophoresis using Coomassie blue. PLoS One 6(8):e22394. doi:10.1371/journal.pone.0022394

32. Q2B IT (1996) Guidelines for validation of analytical procedures: methodology, vol 8. Pharmaeuropa, p 108

33. Krokhin OV, Spicer V (2009) Peptide retention standards and hydrophobicity indexes in reversed-phase high-performance liquid chromatography of peptides. Anal Chem 81(22):9522-9530. doi:10.1021/ac9016693

34. Krokhin OV, Ying S, Cortens JP, Ghosh D, Spicer V, Ens W, Standing KG, Beavis RC, Wilkins JA (2006) Use of peptide retention time prediction for protein identification by off-line reversedphase HPLC-MALDI MS/MS. Anal Chem 78(17):6265-6269. doi:10.1021/ac060251b

35. AL-Bahri MB, AL-Naimi A, Ahammed SH (2009) Study the effect of hydrolysis variables on the production of soya proteins hydrolysis. Al-Khwarizmi Eng J 5(4):25-38

36. Csapá J, Csapó-Kiss Z, Wágner L, Tálos T, Martin TG, Folestad S, Tivesten A, Némethy S (1997) Hydrolysis of proteins performed at high temperatures and for short times with reduced racemization, in order to determine the enantiomers of $\mathrm{D}-$ and L-amino acids. Anal Chim Acta 339:99-107 